3.1 4, 3.28, 3.1 8 for groups I. 2 and 3. respectively. On the other hand, supplementation with a 37 p. Ioo crude protein feed, one meal out of four, every 2 days, gave not only lower growth value ( $483 \mathrm{~g}$ daily mean gain between 20 and $60 \mathrm{~kg}$ live weight and $573 \mathrm{~g}$ between 20 and $90 \mathrm{~kg}$ live weight), poorer utilization of the feed (feed conversion ratio 3.26 during the growth period and 3.45 during the whole fattening period), but also fatter carcasses (backfat thickness, $\frac{\text { loin }+ \text { backfat }}{2} \mathrm{~mm}$ of $23.7,24.2,24.6$ and 27.1 ; percentage of backfat/net weight : 1 5.08, I 5.20, 14.82, 15.96, respectively for groups I, 2, 3 an 4 ).

Delay in protein supplementation over a greater period than 24 hours appeared to be less efficient in growing pigs because the reduced utilization of the nitrogen fraction led to production of fatter carcasses.

\title{
EFFETS D'UN APPORT ELEVE DE CALCIUM SUR LE MÉTABOLISME CALCIQUE CHEZ LE PORC EN CROISSANCE
}

\author{
P. BESANÇON (1) \\ Station de Recherches sur la Nutrition, \\ Centre national de Recherches zootechniques, I. N. R. A., \\ 78350 Jouy en Josas
}

\section{RÉSUMÉ}

L'élévation de l'apport alimentaire de calcium entraine des variations des paramètres cinétiques du métabolisme calcique et du renouvellement minéral osseux. L'étude a porté sur 15 porcs mâles castrés en croissance, répartis en 3 lots, recevant en moyenne 10,15 ou $27 \mathrm{~g}$ de calcium par jour, le rapport $\mathrm{Ca} / \mathrm{P}$ étant maintenu constant dans l'aliment et voisin de $\mathrm{I}, 3$.

La digestibilité du calcium diminue avec l'augmentation des apports, l'utilisation digestive réelle passant de $5 \mathrm{I}, 5$ à 36,0 et 33,0 p. Ioo đans chacun des trois lots ; cependant l'utilisation digestive apparente ne varie pas significativement. L'excrétion fécale de calcium endogène reste en moyenne voisine de $27 \mathrm{mg} / \mathrm{kg}$ poids vif/jour et ne contribue pas à la régulation de l'utilisation digestive.

Au niveau métabolique, l'augmentation de rétention osseuse du calcium qui passe de 3,3 à $7,3 \mathrm{~g} /$ jour, est due non à une vitesse accruc d'incorporation sous la forme d'accrétion, mais plutôt à une réduction d'ostéolyse ou de résorption. In effet, l'accrétion osseuse de calcium reste à peu près constante dans les limites de $\mathbf{9}$ à $\mathbf{I} 2 \mathrm{~g} / \mathrm{jour}$. La réduction de mobilisation du calcium osseux ralentit le renouvellement minéral osseux : la fraction endogène de l'accrétion, représentant des recyclages au niveau de l'os, passe de 55 à $\mathbf{I} 8$ p. Ioo chez les animaux recevant un excès de calcium.

Ces résultats permettent de confirmer les recommandations habituelles d'apport phosphocalcique chez le Porc en croissance. Le besoin est satisfait par un régime contenant $9 \mathrm{~g}$ de calcium par $\mathrm{kg}$ de matière sèche, avec un rapport $\mathrm{Ca} / \mathrm{P}$ de $\mathrm{I}, 3$. L'augmentation de l'apport calcique est inutile et peut avoir un effet défavorable sur le renouvellement de l'os en croissance.

(1) Adresse actuelle : Université des Sciences et Techniques du Languedoc Laboratoire de Physiologie Appliquée 34 -Montpellier. 


\section{SUMMARY}

\section{EFFECTS OF HIGH DIETARY CALCIUM LEVELS ON THE CALCIUM METABOLISM IN GROWING PIGS}

Increasing the dietary supply of calcium leads to variations in the kinetic parameters of calcium metabolism and of bone mineral turnover. The study was made with I 5 growing castrated male pigs, distributed into 3 groups and receiving, on an average, Io, 15 or $27 \mathrm{~g}$ of calcium per day; the $\mathrm{Ca} / \mathrm{P}$ ratio of about $\mathrm{I} .3$ remained constant in the diets.

The digestibility of calcium decreased as the supplies increased, and the real digestive utilization fell from 51.5 to 36.0 and $33.0 \mathrm{p}$. Ioo in each of the three groups. However, the apparent digestive utilization did not change significantly. The faecal excretion of endogenous calcium remained close to $27 \mathrm{mg} / \mathrm{kg}$ live weight/day, on an average, and did not take part in the regulation of digestive utilization.

As regards the metabolism, increase in the retention of calcium by the bone ( 3.3 to $7.3 \mathrm{~g} /$ day) did not depend on a higher rate of incorporation i.e. accretion, but was rather due to a reduction of osteolysis or resorption. In fact, the bone accretion of calcium remained almost constant (between 9 and $12 \mathrm{~g} /$ day), whereas the bone resorption of calcium greatly decreased (6.4-1.9 g/day) as the calcium supply increased. Decrease in the mobilization of bone calcium reduced the bone mineral turnover rate. The endogenous fraction of the accretion fell from 55 to $18 \mathrm{p}$. 100 in the animals receiving an excess of calcium.

These results confirm the usual recommendations as regards the supply of phosphorus and calcium in the growing pig. The requirement is satisfied by a diet containg $9 \mathrm{~g}$ of calcium per $\mathrm{kg}$ dry matter, with a $\mathrm{Ca} / \mathrm{P}$ ratio of $\mathbf{I} .3$. Increase of the calcium supply is useless and may have an unfavourable effect on the turnover of the growing bone. 